\title{
Adult Attachment and Personality Traits and the Quality of Marriage of Husband and Wife Couples
}

\author{
Yuspendi, Lie Fun-Fun, and Cindy Maria \\ Faculty of Psychology \\ Maranatha Christian University
}

\begin{abstract}
The study aimed to increase the quality of marriage by understanding the match between adult attachment and personality traits (which includes agreeableness, conscientiousness, and neuroticism) on marriage quality of couples. Five hundred couples or 1000 participants were recruited with cluster area sampling in five areas of Bandung City, and were asked to complete Marital Satisfaction Scale and Big Five Inventory. Data was analysed using Multiple Regression and Paired-Sample T-Test. Results showed that adult attachment and personality traits both had a simultaneous effect on marriage quality. Adult attachment had a greater effect compared to the three traits mentioned. Agreeableness was found to have a direct effect on marriage quality of couples, while conscientiousness was found to only have a direct effect on husbands, not wives. Neuroticism was not found to have any direct effects on marriage quality. Further paired sample $\mathrm{t}$-test result confirmed these findings.
\end{abstract}

Keywords: adult attachment, personality traits, marriage quality

Studi ini bertujuan meningkatkan kualitas pernikahan dengan memahami kecocokan antara kelekatan dewasa dan ciri-ciri kepribadian (yang meliputi agreeableness, conscientiousness, dan neuroticism) terhadap kualitas pernikahan pasangan. Lima ratus pasangan atau 1000 partisipan telah direkrut dengan cluster area sampling di lima wilayah kota Bandung, dan dimohon mengisi skala kepuasan pernikahan (Marital Satisfaction Scale) dan Big Five Inventory. Data dianalisis dengan regresi ganda dan uji-t sampel berpasangan. Hasil menunjukkan bahwa kelekatan dewasa dan ciri kepribadian keduanya memiliki efek simultan terhadap kualitas pernikahan. Kelekatan dewasa memiliki efek yang lebih besar dibandingkan ketiga ciri yang dikemukakan. Agreeableness ternyata memiliki efek langsung terhadap kualitas pernikahan pasangan, sedangkan conscientiousness hanya memiliki efek langsung terhadap para suami, bukan para istri. Neuroticism tak memiliki sesuatu efek langsung apa pun terhadap kualitas pernikahan. Hasil uji-t sampel berpasangan selanjutnya mengonfirmasi temuan-temuan tersebut.

Kata kunci: kelekatan dewasa, trait kepribadian dan kualitas pernikah

A high number of divorce cases was found in the United States, approaching 50\%, with Canada and Australia with $40 \%$ of all existing marriages ending up in divorce (Sweeper \& Halford, 2006). This situation is also found in Bandung, with divorce rates ranking fourth out of 24 regions in West Java according to data from the High Court retrieved in October 2012.

A main factor influencing divorce in Bandung city is disharmony in the household. This differed from

This research was funded by a DIPA grant (Fundamental Research No. 1089/K4/KM/2014) from Kopertis Wilayah VII, Department of Education and Culture. Correspondence concerning this research should be addressed to Yuspendi, Faculty of Psychology, Maranatha Christian University, Jalan Prof. Suria Sumantri, drg., MPH No. 65. Bandung 40164. E-mail: gyuspendi@yahoo.com. other West Java regions such as Indramayu, that cited economic factors as the main reason for divorce (PTA Bandung, 2013). Lack of harmony in marriage can be caused by the low quality of marriage related to a healthy relationship with partner, intensive communication and being happy with a partner (Fowers \& Olson, 1993).

A study by Mikulincer, Florian, Cowan and Cowan (2002) showed that marriage quality was related to the attachment style of the couple, while according to Ben-Ari and Lavee (2005) quality of marriage was related to personality traits, especially neuroticism.

Attachment is an emotional bond formed by a child with his/her mother, and will influence the development of a secure relationship in the child, further 
helping the child to develop healthy emotions and relationship in the future (Flory, 2005). A mother can create a secure relationship with her child if the mother feels secure herself, because she is the source of security for her child. Psychoanalysis experts state that emotional bond in childhood will have a significant influence in the development of personality and adult adaptation (Yuspendi, 2012).

A child's consistent and prolonged attachment pattern attracted researchers Main and Cassidy (1988) to examine adult attachment empirically and theoretically. They investigated the stability and consistency of attachment across the lifespan by constructing the Adult Attachment Interview (AAI).

Main (1995) conducted a study to test the stability of attachment pattern by constructing AAI to measure the state of mind of adults that was also related to how they relate to their parents. According to the research on the stability and consistency of attachment pattern using the measurement developed by Main and Cassidy (1988), Waters, Crowell, Treboux, Merrick and Albersheim (1995) showed the continuous nature of a child's attachment pattern all through adulthood. According Hazan and Shaver (1987), adult attachment is a reflection of child attachment.

The implication of adult attachment security on partner relationship as suggested by Bowlby (1979) was that a strong causal relationship between a person's experience with their parents exists as a capacity to create emotional bonds with other people. This idea was further developed by Hazan and Shaver (1987) who stated that adult romantic relationship is a manifestation of a behavior similar to attachment pattern.

Bartholomew (cited in Kirkpatrick, 2005) categorized adult attachment into two different patterns: secure and insecure attachment. Secure attachment is when an individual feels easy to be close and comfortable depending on another person, and that person can depend on the said individual. Insecure attachment showed how an individual displayed discomfort or difficulty in trusting others, or conversely the individual could feel that others are distant and as such they will worry about whether their partner truly loves them.

Mikulicer et al., (2002) suggested a systemic model from the relationship between attachment security of couples with their satisfaction of marriage. This is in line with findings by Collins and Reed (1990) and Kirkpatrick and Davis (1994) who found that couples with a secure attachment pattern tend to have a better level of marriage satisfaction compared to those (either one partner or both) with insecure attachment pattern.

Shaver and Brennan (1992, as cited in Crowell and Trenoux, 1995) found that adult attachment had a high correlation with some personality traits, namely neuroticism, extraversion and conscientiousness, but low correlation with openness and conscientiousness. According to Costa and McCrae (as cited in Pervin, Cervone, \& John, 2005) the five personality traits include: (1) openness, shown as high curiousity, broad range of interests, creativity, and imagination; (2) conscientiousness, shown in individuals who possess high levels of planning, organisation, being dependable, hard working, self-disciplined and careful; (3) extraversion, making it easier for individual to socialize, be optimistic, have many friends, and actively seek challenges; (4) agreeableness, shown in individuals with a gentle nature, trustworthy, helpful toward others, (5) neuroticism, shown in individuals who are anxious, nervous, worried, insecure, emotional, and uneasy.

Findings by Griffin and Bartholomew (1994a, as cited in Crowell and Treboux, 1995) showed a high level of correlation between adult attachment, especially with mothers, with trait neuroticism and a moderate correlation with extraversion, openness, and agreeableness. This finding is supported by $\mathrm{Wu}(2005)$ who stated that women had a higher level of neuroticism compared to men in their young adulthood period. The presence of adult attachment as an intrapersonal factor with personality traits will strengthen the quality of marriage in married couples.

Karney and Bradbury (1997) stated that personality traits have an influence in a married couple's marriage satisfaction. Moreover, findings by Mehrabian (1989) showed that similar personality traits between partners was correlated with a stable and happy relationship. From the research by Gattis, Berns, Simpson, and Christensen (2004), it was shown that trait neuroticism, agreeableness, and conscientiousness all have a significant relationship with marriage satisfaction compared to trait extraversion and openness. Gattis et al., (2004) showed marriage satisfaction as one indicator to measure marriage quality.

\section{Theoretical Review}

In this literature review, theories of attachment and personality traits will be explained with their relations with marriage quality, ending with the hypothesis of the current study. 


\section{Attachment}

Bowlby (1969) stated that attachment is a deep emotional bond between a child and his/her caregiver. Such emotional relationship possess an emotional quality shown by the child who feel not only distressed when separated from the caregiver and relief upon being reunited, but also a sense of security felt by the child with the presence of the caregiver.

Bowlby (cited in Pervin et al., 2005) based on clinical observation and literature review formulated attachment behavioural system (ABS) theory. This theory is the result of an effort to illustrate the mechanism of behaviour that contributed to the stability and flexibility of social behaviour (Waters, 1981).

The ABS theory stated that an infant's development goes through a set of phases in the development of attachment with the main caregiver, mainly mother, and that this attachment acts as a secure base for a child in situations of separation and exploration.

After going through the development of ABS, an infant starts to develop internal working models (IWMs) or a mental representation of self and the main caregiver. IWMs are associated with emotion and cognition. According to the interactional experience during infancy, this model gave a base of developing future attachment. This highlights the value of infant attachment on the development of personality and relationship with other people in the future.

From laboratory studies, Ainsworth (1967) categorizes attachment into secure and insecure attachment. Studies on attachment continue on through adulthood. This is in accordance with Bowlby (cited in Kirkpatrick, 2005) that attachment develops across the lifespan where initial attachment will be carried on into adulthood as a model of close relationships with other people. This statement pushed Main et al., (1985) to investigate the stability of attachment patterns across the lifestyle on the same individual.

Main (1995) conducted a six year long research examining the stability of attachment pattern from childhood to adulthood. From this research, the Adult Attachment Interview (AAI) was developed, and this opened up a new field of study regarding attachment on an adult's life. From studies conducted with the AAI in measuring adult attachment, it was known that there was a consistency of attachment styles that are relatively stable across the lifespan on a number of population samples (Main \& Cassidy, 1988; Waters, Crowell, Treboux, Merrick \& Albersheim, 1995).

Referring to the research on adult attachment developed by Main (1995), Bartholomew (as cited in
Kirkpatrick, 2005) stated that adult attachment can be categorized in two parrerns: secure and insecure attachment. These two patterns have a parallel relationship with childhood attachment, with the following characteristics:

Secure attachment, where an individual feels relatively easy to be close and comfortable depending on others and others can easily depend on the individual.

Insecure attachment, consisting of (1) dismissing, shown by individuals who are uncomfortable with others and feel difficult to trust other wholeheartedly, (2) preoccupied, shown by individual who feel that others are reluctant to be close to them. This individual often worries that his/her partner do not truly love them or wants to be with them, however the individual also longs for closeness with his/her partner.

Feeney (cited in Meins, 1997) stated some behavior of adults with secure and insecure attachments. Adults with a secure attachment show involvement and satisfaction in nurturing a relationship with others and partner, have commitment, trust towards others, warmth in a relationship, interdependence, knowing experienced distress and the ability to process distress constructively. On the other hand, insecure adults will show less trust to others, less involvement in developing relationship with others and partner, shows distress in facing conflicts in the environment, hesitant and lacks confidence.

Feeney (as cited in Ben-Ari \& Lavee, 2005) said that the attachment perspective provided a basic understanding of individual differences, in the form of behavior when relating to others that are more specific and individual perceptions on the quality of the relationship. This explanation is in line with the statement by Mikulincer et al., (2002) regarding the significant amount of evidence showing the relationship between adult attachment and quality of relationship with other people.

Numerous studies showed a positive relationship between secure attachment and relationship satisfaction in the form of reports from individuals about marriage satisfaction having a significant relationship with attachment security on attachment security of their life partner (Brennan \& Shaver, 1995; Davilla \& Bradbury, 2001).

\section{Personality}

Allport and Odbert (cited in Beitel, 2002) stated that personality is a capacity that distinguishes the behavior of one individual and another. On the other hand, Pervin et al.(2005) showed that personality is an 
individual's characteristic that led to the emergency of consistent feelings, thoughts, and behavior.

According to Pervin et al., (2005) personality traits refer to the consistent pattern in individual behavior, feelings, or thoughts. When describing a person as having a "good" trait, this means that the said individual tend to act in a good manner from time to time and from one situation to another.

The trait theory according to Costa and McCrae (cited in Pervin et al., 2005) as a five factor theory stated that there are five main traits. In this theory, traits are viewed as a psychological structure that is possessed by every individual with varying levels, analogous to a person's height. The traits are seen to have a causal influence on a person's psychological development. The five factors are the basic tendencies that are universally found in every individual.

Costa and McCrae (cited in Larsen \& Buss, 2005) developed a persality measurement called NEO-PI-R or OCEAN using the Big Five Models approach encompassing Extraversion, Agreeableness, Conscientiousness, Neuroticism, and Openness.

Past research regarding personality traits related to marriage quality showed that traits neuroticism and extraversion have negative relationship with marital well being. Openness, agreeableness, and conscientiousness tend to have a positive relationship with marital well-being, however not all studies showed consistent findings (Kosek, 1996; Robins, Caspi, \& Moffitt, 2000)

Neuroticism is a personality trait that is most consistent in predicting marriage satisfaction, depicting negative feelings or anxiety in general (Karney \& Bradbury, 1995). Neuroticism is a tendency rising from a collection of experiences consisting negative emotions such as worry, anger, disappointment, and embarrassment (Costa \& McCrae, 1985). This definition is in line with Keltner's (1996) statement that neuroticism is a personality trait defined as negative emotion in a positive condition.

Other studies showed trait neuroticism having negative relationship with numerous measurements of marital adjustment (Kurdek, 1997). Based on Kelly and Conley's (1987) longitudinal study on married couples, trait neuroticism was found to predict divorce before or even marriage compared to other personality traits or even other variables.

Trait extraversion according to Costa and McCrae (1985) is a factor encompassing sociable qualities, relating to others, assertiveness, hard work, and talkativeness. Kelly and Conley (1987) found that high trait extraversion on men can be a predictor of divorce, but not on women. However, Lester, Haig, and Monello (1989), from their study of 30 married couples, showed that high trait extraversion on either partner was related to many dissatisfactions in marriage.

Costa and McCrae (1985) further posited trait openness as imaginative quality, acceptance of new ideas, and openness towards new things. Trait openness in the context of marriage is related to high marriage satisfaction for both partners (Botwin, Buss \& Shakelford, 1997; Kosek, 1996). This is also seen on trait agreeableness and conscientiousness that have positive relationships with marriage satisfaction.

\section{Research Question}

The increasing amount of divorce cases in Indonesia, especially in West Java, will have an influence on a child's psychological development. Therefore, it is necessary to increase marriage quality in couples to prevent the occurrence of divorce in the family.

Good quality of marriage is influenced by intrapersonal factors found in each partner, including personality traits such as neuroticism, agreeableness and conscientiousness, as well as interpersonal factors which is adult attachment. Past studies commonly separate these two factors. Studies by Kosek (1996) and Robin et al., (2000) found that personality traits were related to quality of marriage, while Brennan and Shaver (1995) and Davilla and Bradbury (2001) showed an effect of secure attachment on relationship satisfaction. The researcher of this current study is interested to investigate intrapersonal and interpersonal factors simultaneously on the quality of marriage.

The research questions to be answered in this study is (1) what role do adult attachment and personality traits have in determining quality of marriage; (2) how do roles of adult attachment and personality traits match in determining quality of marriage. These meant that there are no difference between adult attachment, personality traits, and marriage quality between husband and wife.

\section{Aim of study}

The aim of the current study is to acquire factors influencing quality of marriage by simultaneously testing the variable adult attachment and personality traits on each structural pathways and to do differential testing on couple samples to determine the match of adult attachment and personality traits on marriage quality. 
The hypotheses of the current study were as follows: (1) adult attachment and personality traits simultaneously affect quality of marriage on husbands in Bandung city;

(2) adult attachment and personality traits simultaneously affect quality of marriage on wives in Bandung city;

(3) there would be no significant difference which means that a match between adult attachment and personality traits can increase quality of marriage on married couples in Bandung.

\section{Method}

The current study is a non-experimental quantitative study. The role of adult attachment and personality traits on married couple's quality of marriage in Bandung city will be analysed.

The following measurement instruments will be used. The first was the Marital Satisfaction Scale (MSS), which was modified from Marital Satisfaction Inventory (MSI) from Snyder (Fower \& Olson, 1993). An example item is: Marriage restrains me.

The couple's attachment is measured with Experiences in Close Relationships (ECR) Inventory Adult Attachment Questionnaire developed by Brennan, Clark, and Shaver (1998). This measurement is a collection of 482 items developed from the literature regarding attachment. From these items, a factor analysis method was done with a large number of samples. From 60 subscales, two important were acquired: avoidance, and anxiety. Each dimension was represented by 18 items with a reliability value of .91 to .94 .

The combination of the two dimensions avoidance and anxiety will determine attachment style, which are secure and insecure attachment. If scores or the two dimensions are high, an adult will be considered as having a secure attachment. On the other hand, low scores on either or both dimensions will be considered as insecure attachment. An example item for avoidance dimension is: I am comfortable being close to my partner. An example item for anxiety is: I worry a lot about losing my partner.

Personality is measured using the Big Five Inventory (BFI) developed by John, Donahue, and Kentle (1991, as cited in Pervin \& John, 1999) consisting of 44 items from expert ratings and factor analysis. It consisted of 8 to 10 items for each personality trait, using short phrases. Results of this scale were compared with Trait Description Adjective
(TDA) from Goldberg (1992, as cited in Pervin \& John , 1999)) and NEO-FFI from Costa and McCrae (1992, as cited in Pervin \& John , 1999).

Alpha reliability coefficient showed the highest score belonged to TDA (.89), followed by BFI (.83) and NEO-FFI (.79). Average score from convergent validity correlated to the three measurements showed BFI and TDA (.81) followed by BFI and NEO-FFI (.73) and lastly TDA and NEO-FFI (.68). Average score from convergent reliability showed BFI and TDA (.95) being the highest, followed by BFI and NEO-FFI (.93) and TDA and NEO-FFI (.83). These results showed that on two measurement scales for personality traits, BFI had high validity and reliability especially relating to TDA. An example of BFI item: I see myself as a talkative person.

The chosen measurements were then tested on 100 respondents. The respondents were couples aged 1845 years old, first marriage, and monogamously living in Bandung. Data was collected with cluster area sampling in five areas of the city which include Central Bandung, West Bandung, East Bandung, North Bandung, and South Bandung with 100 participants in each area, with a total of 500 husbandwife pairs. Data was collected by five field coordinators aided by 25 assistant field coordinators who were trained to come directly to respondent's house and accompany them throughout the completion of the questionnaire (to prevent couples from working together).

Data was processed with MANOVA statistical test to test the hypothesis regarding the role of adult attachment and personality trait on quality of marriage separately on husbands and on wives. Next, a pairedsample t-test was conducted to test the hypothesis related to the match of role between adult attachment and personality traits on quality of marriage of couples.

\section{Results}

Data was collected from 1000 participants (500 couples) spread throughout Central, West, North, South, and East Bandung. Each district was represented by 100 husband-wife couples. The following are a description of the respondents. Age of husbands were on average 33 years old with a mode of $40(13.4 \%)$, whereas wives were on average 31 years old with a mode of 32.

In terms of the level of education, husbands were most commonly high school (37\%) and bachelor's 
Table 1

Inter-variable Correlation

\begin{tabular}{llrrrrr}
\hline & Aasuami & Agsuami & Cosuami & Nesuami & Mssuami \\
\hline Aasuami & Pearson Correlation & 1 & $.254^{* * *}$ & $.201^{* *}$ & $-.297^{* * *}$ & $.530^{* *}$ \\
& Sig. (1-tailed) & & .000 & .000 & .000 & .000 \\
& $N$ & 500 & 500 & 500 & 500 & 500 \\
Agsuami & Pearson Correlation & $.254^{* *}$ & 1 & $.505^{* * *}$ & $-.297^{* * *}$ & $.422^{* * *}$ \\
& Sig. (1-tailed) & .000 & & .000 & .000 & .000 \\
& $N$ & 500 & 500 & 500 & 500 & 500 \\
Cosuami & Pearson Correlation & $.201^{* *}$ & $.505^{* * *}$ & 1 & $-.367^{* * *}$ & $.325^{* *}$ \\
& Sig. (1-tailed) & .000 & .000 & & .000 & .000 \\
& $N$ & 500 & 500 & 500 & 500 & 500 \\
Nesuami & Pearson Correlation & $-.297^{* *}$ & $-.297^{* *}$ & $-.367^{* *}$ & 1 & $-.274^{* *}$ \\
& Sig. (1-tailed) & .000 & .000 & .000 & & .000 \\
& $N$ & 500 & 500 & 500 & 500 & 500 \\
Mssuami & Pearson Correlation & $.530^{* *}$ & $.422^{* * *}$ & $.325^{* *}$ & $-.274^{* * *}$ & 1 \\
& Sig. (1-tailed) & .000 & .000 & .000 & .000 & 500 \\
& $N$ & 500 & 500 & 500 & 500 & 500 \\
\hline
\end{tabular}

Note. **Correlation is significant at the .01 level (1-tailed).

Aasuami : adult attachment, Agsuami : trait agreeableness, Cosuami : trait conscientiousness,

Nesuami : trait neuroticism, Mssuami : marital satisfication

Table 2

ANOVA $^{b}$

\begin{tabular}{clcrrrr}
\hline Model & & Sum of Squares & Df & Mean Square & $F$ & Sig. \\
\hline 1 & Regression & 80620.190 & 4 & 20155.048 & 75.521 & $.000^{\mathrm{a}}$ \\
& Residual & 132105.098 & 495 & 266.879 & & \\
& Total & 212725.288 & 499 & & & \\
\hline
\end{tabular}

Note. a. Predictors: (Constant), Nesuami, Agsuami, Aasuami, Cosuami. b. Dependent Variable: Mssuami

degree (32.8\%), others were on Diploma, junior high school, elementary school, Master's, $\mathrm{PhD}$, and $4 \%$ never attended school. This is similar to wives, with high school being most common $(35.2 \%)$ and bachelor's degree $(30 \%)$. Others were on Diploma, junior high school, elementary school, Master's, and $2 \%$ never attended school.

A majority of husbands were Sundanese (47\%), Javanese $(19.8 \%)$, and Chinese (19\%). Wives were mostly Sundanese (50\%), with Chinese (19.4\%) and Javanese $(17.6 \%)$ being the two next most common ethnicities. A majority of respondents were Muslim (63\%). The rest were Protestants, Catholics, and Buddhists.

A majority of couples have one or two children (72.2\%), and $21.4 \%$ do not have children. The rest had three to five children (6.4\%)

Correlation scores on Table 1 between adult attachment and personality traits on quality of marriage in husbands were -.274 to .530 , with a significance value of .000 meaning the correlation between the variables are significant.

Significance test results were presented in Table 2. ANOVA showed $F$ value of 75.521 with a signi- ficance value of .000 . Compared with $\alpha=.05$, the significance value is lower than $\alpha(\mathrm{Sig} . \leq \alpha)$. This means that $\mathrm{Ho}$ is rejected and $\mathrm{H} 1$ accepted. This meant that adult attachment and personality trait of husbands played a simultaneous and significant role in quality of marriage in Bandung city.

Result of sub-structural pathway analysis resulted in the following standardized coefficients $(\beta)$ :

(1). Adult attachment has a direct and significant effect on quality of marriage on husbands with $\beta$ coefficient of .437 and significance value of .000 .

(2). Trait agreeableness has a direct and significant effect on quality of marriage on husbands with $\beta$ coefficient of .252 and significance value of .000 .

(3). Trait conscientiousness has a direct and significant effect on quality of marriage on husbands with $\beta$ coefficient of .098 and significance value of .021.

(4). Trait neuroticism did not have a direct and significant effect on quality of marriage on husbands with $\beta$ coefficient of -.033 and significance value of .402 .

Correlation results presented in Table 3 between adult attachment and personality traits range from .168 to .463 with a significance value of .000 . This 
Table 3

Correlations

\begin{tabular}{|c|c|c|c|c|c|c|}
\hline & & Aaistri & Agistri & Coistri & Neistri & Msistri \\
\hline \multirow{3}{*}{ Aaistri } & Pearson Correlation & 1 & $.164^{* * *}$ & $.245^{* * *}$ & $-.196^{* *}$ & $.463^{* *}$ \\
\hline & Sig. (1-tailed) & & .000 & .000 & .000 & .000 \\
\hline & $N$ & 500 & 500 & 500 & 500 & 500 \\
\hline \multirow[t]{3}{*}{ Agistri } & Pearson Correlation & $.164^{* *}$ & 1 & $.505^{* *}$ & $-.330^{* *}$ & $.361^{* *}$ \\
\hline & Sig. (1-tailed) & .000 & & .000 & .000 & .000 \\
\hline & $N$ & 500 & 500 & 500 & 500 & 500 \\
\hline \multirow[t]{3}{*}{ Coistri } & Pearson Correlation & $.245^{* *}$ & $.505^{* *}$ & 1 & $-.381^{* *}$ & $.301^{* *}$ \\
\hline & Sig. (1-tailed) & .000 & .000 & & .000 & .000 \\
\hline & $N$ & 500 & 500 & 500 & 500 & 500 \\
\hline \multirow[t]{3}{*}{ Neistri } & Pearson Correlation & $-.196^{* *}$ & $-.330^{* *}$ & $-.381^{* *}$ & 1 & $-.168^{* *}$ \\
\hline & Sig. (1-tailed) & .000 & .000 & .000 & & .000 \\
\hline & $N$ & 500 & 500 & 500 & 500 & 500 \\
\hline \multirow[t]{3}{*}{ Msistri } & Pearson Correlation & $.463^{* *}$ & $.361^{* *}$ & $.301^{* *}$ & $-.168^{* *}$ & 1 \\
\hline & Sig. (1-tailed) & .000 & .000 & .000 & .000 & \\
\hline & $N$ & 500 & 500 & 500 & 500 & 500 \\
\hline
\end{tabular}

Note. $\quad * *$ Correlation is significant at the .01 level (1-tailed).

Aaistri: adult attachment, Agistri: trait agreeableness, Coistri: trait conscientiousness, Neistri: trait neuroticism, Msistri : marital satisfication

Table 4

ANOVA ${ }^{b}$

\begin{tabular}{llccccr}
\hline Model & & Sum of Squares & Df & Mean Square & $F$ & Sig. \\
\hline 1 & Regression & 68736.083 & 4 & 17184.021 & 53.648 & $.000^{\mathrm{a}}$ \\
& Residual & 158553.549 & 495 & 320.310 & & \\
& Total & 227289.632 & 499 & & & \\
\hline
\end{tabular}

Note. a. Predictors: (Constant), Neistri, Aaistri, Agistri, Coistri

b. Dependent Variable: Msistri

Table 5

Coefficients

\begin{tabular}{|c|c|c|c|c|c|}
\hline \multirow[t]{2}{*}{ Model } & \multicolumn{2}{|c|}{ Unstandardized Coefficients } & \multirow{2}{*}{$\begin{array}{c}\text { Standardized Coefficients } \\
\text { Beta }\end{array}$} & \multirow[b]{2}{*}{$T$} & \multirow[b]{2}{*}{ Sig. } \\
\hline & $B$ & Std. Error & & & \\
\hline (Constant) & 43.519 & 10.857 & & 4.008 & .000 \\
\hline Aaistri & .449 & .043 & .407 & 10.427 & .000 \\
\hline Agistri & 1.533 & .257 & .264 & 5.971 & .000 \\
\hline Coistri & .408 & .236 & .079 & 1.731 & .084 \\
\hline Neistri & -.144 & .202 & -.029 & -.710 & .479 \\
\hline
\end{tabular}

Note. $\quad$ b. Dependent Variable: Msistri

means that the intervariable correlations were significant. However, trait neuroticism results were not in line with the current hypothesis.

Significance testing results on Table 4 showed an ANOVA result with $F$ value of 53.648 and a significance of .000 . Compared with $\alpha=.05$, the significance value is lower than $\alpha($ Sig. $\leq \alpha)$. This means that $\mathrm{H} 0$ is rejected and $\mathrm{H} 1$ accepted. This meant that adult attachment and personality trait of wives played a simultaneous and significant role in quality of marriage in Bandung city.

Result of sub-structural pathway analysis presented in Table 5 resulted in the following standardized coefficients $(\beta)$ :
1. Adult attachment has a direct and significant effect on quality of marriage on wives with $\beta$ coefficient of .407 and significance value of .000 .

2. Trait agreeableness has a direct and significant effect on quality of marriage on wives with $\beta$ coefficient of .264 and significance value of .000 .

3. Trait conscientiousness did not have a direct and significant effect on quality of marriage on wives with $\beta$ coefficient of .079 and significance value of .479 .

4. Trait neuroticism did not have a direct and significant effect on quality of marriage on wives with $\beta$ coefficient of -.029 and significance value of .402 . 
Table 6

Paired Samples Correlations

\begin{tabular}{lccc}
\hline & $N$ & Correlation & Sig. \\
\hline Pair 1 Aasuami \& Aaistri & 500 & .506 & .000 \\
Pair 2 Agsuami \& Agistri & 500 & .283 & .000 \\
Pair 3 Cosuami \& Coistri & 500 & .244 & .000 \\
Pair 4 Nesuami \& Neistri & 500 & .172 & .000 \\
Pair 5 Mssuami \& Msistri & 500 & .521 & .000 \\
\hline
\end{tabular}

Correlation results in Table 3 between adult attachment and personality traits range from -.029 to .407 with a significance value of .000 which meant that the intervariable correlations were significant. Two personality traits, namely conscientiousness and neuroticism on wives, were not in line with the hypothesis of the current study.

Results of paired sample t-test (Table 7) relating to adult attachment of couples showed a significance value of .064. Compared to $\alpha=.05$, significance value is greater than $\alpha$, meaning that $\mathrm{H} 0$ is accepted and $\mathrm{H} 1$ rejected. This showed no difference or a match of adult attachment on couples in Bandung city. The coefficient size of adult attachment's role on couples based on paired-samples correlations was .506 with significance value of .000 (see Table 6).

Result of significance testing on personality traits (Table 7) showed traits agreeableness and conscientiousness of husbands and wives having significance values of .975 and .936 respectively. Compared to $\alpha=.05$, significance value is greater than $\alpha$ (Sig. $\leq \alpha)$, meaning that $\mathrm{H} 0$ is accepted and $\mathrm{H} 1$ rejected. This showed no difference or a match between personality traits agreeableness and conscientiousness on marriage quality of couples in Bandung city. The size of correlation coefficient of trait agreeableness and trait conscientiousness on couples based on paired samples correlations were .283 and .244 with a significance value of .000 (see
Table 6).

Significance testing results on Table 3 showed that trait neuroticism of husbands and wives had a significance value of .000 . Compared to $\alpha=.05$, significance value is lesser than $\alpha(\mathrm{Sig} . \leq \alpha)$, which is $.000<.05$. This means that $\mathrm{H} 0$ is rejected and $\mathrm{H} 1$ accepted. This showed a difference or lack of match between trait neuroticism on quality of marriage of couples in Bandung. Despite the results, trait neuroticism on couples based on paired samples correlations (.172 with significance value of .000) still had a significant correlation coefficient (see Table 6) even though it is considerably smaller compared to the two other traits' correlation coefficients.

Paired sample t-test results relating to quality of marriage showed a significance value of .990 (Table 7). Compared to $\alpha=.05$, significance value is greater than $\alpha$ which meant that $\mathrm{H} 0$ is accepted and $\mathrm{H} 1$ rejected. This showed no difference or a match between marriage quality of couples in Bandung city. The size of correlation coefficient of the role of adult attachment based on paired samples correlations is .521 with significance value .000 (see Table 6).

\section{Discussion}

Good quality of marriage on couples is influenced by each partner's intrapersonal factors consisting of adult attachment and personality traits, especially traits neuroticism, agreeableness and conscientiousness. Research from Kosek (1996), Robin, Caspi, and Molfitt (2000), Kelly and Conley (1987) provided evidence on the influence of personality traits on marriage quality, while studies by Mikulincer (2002), Brennan and Shaver (1995), Davilla and Bradbury (2001) showed the effects of attachment style and quality of relationship with partner.

Tabel 7

Paired Samples Test

\begin{tabular}{|c|c|c|c|c|c|c|c|c|c|}
\hline & & \multicolumn{5}{|c|}{ Paired Differences } & \multirow{3}{*}{$T$} & \multirow{3}{*}{$D f$} & \multirow{3}{*}{$\begin{array}{c}\text { Sig. } \\
\text { (2-tailed) }\end{array}$} \\
\hline & & \multirow[t]{2}{*}{ Mean } & \multirow[t]{2}{*}{$\begin{array}{c}\text { Std. } \\
\text { Deviation }\end{array}$} & \multirow[t]{2}{*}{$\begin{array}{c}\text { Std. Error } \\
\text { Mean }\end{array}$} & \multicolumn{2}{|c|}{$\begin{array}{l}\text { 95\% Confidence } \\
\text { Interval of the } \\
\text { Difference }\end{array}$} & & & \\
\hline & & & & & Lower & Upper & & & \\
\hline Pair 1 & Aasuami - Aaistri & -1.630 & 19.616 & .877 & -3.354 & .094 & -1.858 & 499 & .064 \\
\hline Pair 2 & Agsuami - Agistri & -.006 & 4.364 & .195 & -.389 & .377 & -.031 & 499 & .975 \\
\hline Pair 3 & Cosuami - Coistri & .018 & 4.981 & .223 & -.420 & .456 & .081 & 499 & .936 \\
\hline Pair 4 & Nesuami - Neistri & -1.156 & 5.491 & .246 & -1.638 & -.674 & -4.707 & 499 & .000 \\
\hline Pair 5 & Mssuami-Msistri & -.012 & 20.557 & .919 & -1.818 & 1.794 & -.013 & 499 & .990 \\
\hline
\end{tabular}


Results from the current study showed that adult attachment and personality traits have a simulatenous and significant effects on the quality of marriage on husbands in Bandung. The role of adult attachment and three personality traits of husbands had a greater simultaneous effect on marriage if compared with the role of each sub-structural pathways from adult attachment and personality traits on marriage quality on husbands. This means that adult attachment and personality traits will have a better influence on increasing quality of marriage if both were considered together rather than separately.

Results from each substructural pathway revealed that adult attachment had a direct and significant effect on marriage quality of husbands in Bandung. This result is in accordance with the findings by Mikulincer et al., (2002) on their study regarding the effects of adult attachment and quality of relationship with others.

Results of analyses related to personality traits of husbands showed that trait agreeableness had a direct and significant effect on husband's perception of marriage quality. This showed that husbands who are agreeable are more sensitive to their partner, are trustworthy, and are ready to help, all of which resulted in better marriage quality. Indeed, Kelly and Conley (1987) found that low agreeableness on husbands, but not on wives, were related to divorce problems. On the other hand, Botwin et al., (1997) found that high agreeableness on either partner was correlated with high marriage satisfaction.

Trait conscientiousness had a significant, direct role on marriage quality in husbands in Bandung. This is in line with Botwin et al.'s (1997) finding that showed how a high level of conscientiousness on one partner is related to high marriage satisfaction.

Trait neuroticism was not found to have a direct, significant effect on husband's quality of marriage. This finding is contradictory to past studies showing that neuroticism is the most consistent trait in predicting marriage satisfaction, depicting negative feelings or general anxiety (Karney \& Bradbury, 1995). Trait neuroticism will have an effect if simultaneously considered with other traits on marriage quality in husbands.

Results of analysis related to adult attachment and personality traits on marriage quality on wives showed that both variables have a simultaneous, significant effect. The simultaneous effect of adult attachment and three personality traits on wives were greater when compared with each individual sub-pathway of adult attachment and personality traits on marriage quality of wives in Bandung.
From the results of sub-structural pathway analysis, it was found that adult attachment had a significant, direct effect on marriage quality on wives in Bandung. This result is in line with the finding by Brennan and Shaver (1995) who stated that there existed a strong relationship between secure attachment and relationship satisfaction on marriage quality of wives.

From the three personality traits possessed by wives, trait agreeableness showed sensitivity to partner, willingness to help, trustworthiness, and all these contribute to good quality of marriage. This is in line with Botwin, Buss, and Shakefold'study (1997) that showed how having a high trait agreeableness on either partner is correlated with high marriage satisfaction.

Trait conscientiousness did not have a direct, significant effect on wives' perception of marriage quality. This is not in line with the result by Botwin et al., (1997) who found that high trait conscientiousness on one partner will lead to high marriage satisfaction. Wives with high trait conscientiousness possess characteristics such as reliability, hardworking nature, being organised and determined, which all contributed to good quality of marriage. Trait conscientiousness in the present study was not found to have a direct effect on marriage quality perhaps due to the fact that most of the wives included in the sample are housewives. As such trait conscientiousness tends to be directly related to the solid management of daily household activities which need planning, organization, selfdiscipline, punctuality; and ambition to achieve certain purposes, besides hard work, neatness and conscientiousness (Pervin et al., 2005). These traits could be seen more in working wives than those who stay home.

Trait neuroticism did not have a direct effect on wives' perception of marriage quality. This is not in accordance with past studies showing that neuroticism is a consistent trait in predicting marriage satisfaction describing negative feelings of generalised anxiety (Karney \& Bradbury, 1995).

The result of the last analysis relating to the match between adult attachment and personality traits on couples in Bandung showed a match between husbands and wives adult attachment style on marriage quality. This means that if a husband has a secure attachment, his wife will usually have a secure attachment as well. Similarly, husbands with insecure attachment will have a wife with insecure attachment. This condition is related to the quality of marriage of couples, shown by their rating of marriage satisfaction.

According to Feeney (cited in Meins, 1997) couples with secure adult attachment will display 
involvement and satisfaction in nurturing relationship with others, have commitment, trust to others, warmth in relating to others, interdependency, knows his/her distress and the ability to process distress in a constructive manner. This condition makes it easier for couples to feel close and comfortable with the partner, resulting in feeling of happiness with them. This can be considered as an indicator of satisfaction marriage, which also means having a good quality of marriage.

From the explanation above, it can be concluded that a match between couples' attachment styles can be useful to prevent divorce especially on divorce cases that happens due to psychological factors. Thus, it can be suggested that couples form secure attachment to form good emotional bond from couples through giving attention and a balance of take-andgive. This should hopefully make it easier for couples to be close to each other, resulting in increased feelings of happiness.

On couples with trait agreeableness, it was shown that there was no difference (in other words there's a match) between couples who both possess trait agreeableness with quality of marriage (Table 7). This is similar to couples with trait conscientiousness who also showed no difference, or a match, between them on marriage quality.

Contradictory evidence was found regarding couples with trait neuroticism. Specifically, it was found that couples with trait neuroticism did not have a match between them that could influence quality of marriage. This is shown by how trait neuroticism did not directly influence quality of marriage of couples in Bandung; there was no clear correlation pattern between trait neuroticism and quality of marriage. This finding is in direct contrast to past results that showed how trait neuroticism could directly predict quality of marriage (Karney \& Bradbury, 1995).

\section{Limitations and Future Research}

Methodological limitation of the current study is the sampling technique, the area cluster sampling, where data collection tended to be accidental in each area. In each cluster, respondents are often taken in concentrated spots, not from an evenly-spread area as it ideally should be. For future data collection methods, it would be better to predict the number of husband-wife couples that match the sample criteria in each cluster. Data could then be collected with a more proportionate ratio on each cluster based on the number of couples in each area.

\section{Conclusion}

Based on the results and discussion earlier, a number of conclusions can be taken:

The role of adult attachment and personality traits are simultaneous and significant on couples' marriage quality. Taken together, both variables will result in a larger coefficient value compared to when the variables were considered separately.

1. Sub pathway analysis was found on both husbands and wives, and it showed that adult attachment has a more significant role compared to the three personality traits (agreeableness, conscientiousness, and neuroticism) on quality of marriage.

2. Trait agreeableness had a direct, significant effect on marriage quality of husbands and wives, whereas trait conscientiousness was shown to have a direct and significant effect on marriage quality only on husbands, not on wives.

3. Trait neuroticism in past studies was shown to be the most consistent in predicting marriage quality, however in the current study it was not found to have a direct or significant effect on the quality of marriage on either husband or wife.

4. There was a match between adult attachment and quality of marriage on couples, as well as a match of traits agreeableness and conscientiousness. Trait neuroticism was not found to have a match on couples' perception of marriage quality.

\section{Suggestions}

Based on the analysis of subpathways, it was found that adult attachment had a bigger impact on quality of marriage. According to Bowlby (cited in Kirkpatrick, 2005), attachment is formed throughout the lifespan, and its effects will be carried on from childhood through adulthood as a model to relate with other people. Hazan and Shaver (1987) noted that adult attachment is a reflection of child attachment. This means that the emotional bond of parent and children has an important role in children's future quality of life. This implies that attachment stability could be seen as an avenue for future research. Future studies could be done to investigate the effects of attachment before and after marriage. A practical implication would be the idea that paretns have a role to create a secure attachment style on children, because this will have an impact on the children's quality of marriage in the future.

From an analysis of three personality traits, it was shown that agreeableness had a direct effect with the 
largest $\beta$ coefficient. This highlights the importance of trait agreeableness in married life. This trait can be emulated by showing sensitivity to partner, increasing trustworthiness, or trying to be more willing to help the partner to increase the quality of marriage.

Trait neuroticism did not have a direct effect on husbands or wives in predicting marriage quality. There did not seem to be a match between husbands or wives related to the feeling of anxiety, worry, and irritability. This could be due to the influence of an Eastern culture, where people are not expected to show negative emotions directly to other people. Therefore, couples need to harmonize and be open in expressing emotions to increase marriage quality. In addition, wives need to further develop trait agreeableness to reduce suspicion, being easily offended, lack of cooperation, or vengeful feelings towards husbands.

For society or government institutions, the National Family Planning institution could help parents form a secure attachment style with their children, so that this secure attachment will be carried through to the children's adult life. This is because adult attachment was found to have a significant effect on couples' marriage quality. Parents could be trained to form secure attachment to help them understand the important aspects of nurturing a relationship with their children as well as with their partner. This could be seen as an indirect, preventative effort to reduce the number of potential divorce cases.

For married couples, showing a match of adult attachment and trait agreeableness could increase quality of marriage. This condition will make couples relatively more at ease with being close to the partner, to depend on the partner, and as a result will increase feelings happiness in their married life.

\section{References}

Ainsworth, M. D. S. (1967). Infancy in Uganda: Infant care and the growth of love. Baltimore: John Hopkins University Press.

Beitel, M. (2002). The effect of psychological mindedness upon the relationships between personality and attachment style: A structural equation model (Unpublished dissertation). Fordham University, New York.

Ben-Ari, A. \& Lavee, Y. (2005). Dyadic characteristic of individual attributes: Attachment, neuroticsm, and their relation to marital quality and closeness. American Journal of Orthopsychiatric, 75, 621- 631.
Botwin, M. D., Buss, D. M., \& Shakefold, T. K. (1997). Personality and mate preferences: Five factors in mate selection and marital satisfaction. Journal of Personality, 65, 107-136.

Bowlby, J. (1979). The making and breaking of affectional bond. London: Tavistock.

Bowlby, J. (1969). Attachment and loss (Vol.2): Attachment. New York: Basic Books.

Brennan, K. A., Clark, C. L., \& Shaver, P. R. (1998). Self-report measures of adult attachment: An integrative overview. Retrieved from http://www. psych.uiuc.edu/rcraley/measures/brennan.htlm.

Brennan, K., \& Shaver, P.R. (1995). Dimension of adult attachment, affect regulation, and romantic relationship functioning. Personality and Social Psychology Bulletin, 21, 567-583.

Collins, N. L., \& Read, S. J. (1990). Adult attachment working models, and relationship quality in dating couples. Journal of Personality and Social Psychology, 58, 644-663.

Costa, P. T., \& McCrae, R. R. (1985). The NEO personality inventory: Manual. Odessa, FL: PARPsychological Assessment Resources.

Crowell, J. A., \& Treboux, D. (1995). A review of adult attachment measures: Implications for theory and research. Social Development, 4, 294-327.

Davila, J., \& Bradbury, T. N. (2001). Attachment insecurity and the distinction between unhappy spouse who do and do not divorce. Journal of Family Psychology, 15, 371-393.

Flory, V. (2005). Your child's emotional need. Sydney: Finch Publishing.

Fowers, B. J., \& Olson, D. H. (1993). ENRICH marital satisfaction scale: Brief research and clinical tool. Journal of Family Psychology, 7, 176-185.

Gattis, K.S., Berns, S., Simpson, L.E. \& Christensen, A. (2004). Bird of a father or strange birds? Ties among personality dimensions, similarity, and marital quality. Journal of Family Psychology, 18, 564-574.

Hazan, C., \& Shaver, P. (1987). Romantic love conceptualized as an attachment process. Journal of Personality and Social Psychology, 52, 511-524.

Karney, B.R., \& Bradbury, T. N. (1997). Neuroticism, marital interaction, and trajectory of marital satisfaction. Journal of Personality and Social Psychology, 72, 1075-1092.

Karney, B. R., \& Bradbury, T.N. (1995). The longitudinal course of marital quality and stability: A Review of theory, method, and research. Psychological Bulletin, 118, 3-34.

Kelly, E. L., \& Conley, J. J. (1987). Personality and 
compability: A prospective analysis of marital satisfaction. Journal of Personality and Social Psychology, 52, 27-40.

Keltner, D. (1996). Facial expressions of emotion and personality. In C. Magai \& S. H. McFadden (Eds.), Handbook of emotion, adult development, and aging (pp. 385 - 401). San Diego, CA: Academic Press.

Kirkpatrick, L. A. (2005). Attachment, evolution, and the psychology of religion. New York: The Gulford Press.

Kirkpatrick, L. A., \& Davis, K. E. (1994). Attachment style, gender, and relationship stability: A longitudinal analysis. Journal of Personality and Social Psychology, 66, 502-512.

Kosek, R. B. (1996). The quest for a perfect spouse: Spousal ratings and marital satisfaction. Psychological Report, 79, 731-735.

Kurdek, L.A. (1997). Marital stability and changes in marital quality in newlywed couples: A test of the contextual model. Journal of Social and Personality Relationship, 8, 27-28.

Larsen, R. J., \& Buss, D. M. (2005). Personality psychology: Domains of knowledge about human nature (2nd ed.). New York : McGraw-Hill.

Lester, D., Haig, C., \& Monello, C. (1989). Spouses' personality and marital satisfication. Personality and Individual Differences, 10, 253 - 254.

Main, M. (1995). Recent studies in attachment: Overview, with selected implications for clinical work. In S.Goldberg, R. Muir, R., and J. Kerr (Eds.), Attachment theory: Social developmental and clinical perspective (pp. 407-474). Hillsdale, NJ: The Analytic Press.

Main, M., \& Cassidy, J. (1988). Categories of response to reunion with the parent at age six: Predictable from infant attachment classification and stable over a one-month period. Developmental Psychology, $24,415-426$.
Mehrabian, A. (1989). Marital choice and compatibility as a function of trait similarity-dissimilarity. Psychological Report, 65, 1202-1202.

Meins, E. (1997). Security of attachment and the social development of cognition. Hove, UK: Psychology Press.

Mikulincer, M., Florian, V., Cowan, P.A., \& Cowan, C.P. (2002). Attachment security in couple relationships: A systemic model and its implications for family dynamic. Family Process, 41, 405-434.

Pervin, L. A., \& John, O. P. (1999). Handbook of personality: Theory and research. (2nd ed.). New York: The Guilford Press.

Pervin, L.P., Cervone, D., \& John, P.J. (2005). Personality theory and research. (9th ed.). USA: John Wiley and Sons, Inc.

PTA Bandung. (2012). Faktor penyebab perceraian. Retrieved from www.pta-bandung.go.id/faktorpenyebab-perceraian.html

Robin, R. W., Caspi, A., \& Moffitt, T. E. (2000). Two personalities, one relationship: Both partner's personality traits shape the quality of their relationship. Journal of Personality and Social Psychology, 79, 251-259.

Sweeper, S. \& Halford, K. (2006). Assessing adult adjusment to relationship separation : The psychological adjusment to separation test (PAST). Journal of Family Psychology, 20, 632-640.

Waters, E., Crowell, J., Treboux, D., Merrick, S. \& Albersheim, L. (1995). Secure attachment from infancy to early adulthood: A 20-years longitudinal study. Paper presented at the Biennial Meeting of the Society for Research in Child Development. Indianapolis, IN

Yuspendi (2013). The role of mother personality traits and mind-mindedness as mediators of mother attachment toward child attachment. Anima Indonesian Psychological Journal, 28(2), 63-74. 